\title{
Uji Performa Kompor Surya Tipe Parabola Silinder Menggunakan Reflektor Cermin dengan Variasi Bahan Absorber
}

\author{
Adinda Ayuning Amri ${ }^{1}$, Mokhammad Nuruddin ${ }^{1)}$, Risse Entikaria Rachmanita ${ }^{1)^{\star}}$ \\ 1) Prodi Teknik Energi Terbarukan, Jurusan Teknik, Politeknik Negeri Jember \\ Naskah diterima 26/01/2020; direvisi 01/04/2020; disetujui 15/04/2020 \\ doi: https://doi.org/10.24843/JEM.2020.v13.i01.p02
}

\begin{abstract}
Abstrak
Kompor surya tipe parabola silinder berbentuk setengah tabung dengan ukuran diameter $43 \mathrm{~cm} \times 63 \mathrm{~cm}$, memiliki variasi bahan absorber yaitu alumunium, tembaga dan kuningan dengan ukuran diameter $41 \mathrm{~cm} \times 61 \mathrm{~cm}$ dan ketebalan 0,02 mm. Pemilihan bahan yang digunakan terdapat pada nilai konduktivitas bahan. Uji performa dilakukan selama 6 hari mulai pukul 10:00-14:00 atau selama 240 menit, meliputi pengukuran radiasi matahari, suhu air, suhu absorber dan suhu lingkungan. Pengujian dilakukan di Gedung Teknik Politeknik Negeri Jember. Data hasil pengukuran digunakan untuk menghitung daya masak, daya masak standart dan efisiensi kompor surya. Suhu tertinggi air pemasakan terdapat pada kompor surya bahan absorber kuningan pada pengujian ke-5 sebesar $80,25{ }^{\circ} \mathrm{C}$ pukul 12:20, daya masak tertinggi pada pengujian hari ke-4 kompor surya bahan absorber aluminium yaitu sebesar 18,46 W, efisiensi kompor tertinggi terdapat pada kompor bahan alumunium pada pengujian pertama sebesar 25,57\% pukul 13:10 WIB. Nilai efisiensi yang dihasilkan dipengaruhi radiasi matahari, beda suhu awal dan akhir serta lama waktu dalam proses pemasakan.
\end{abstract}

Kata kunci: Kompor surya tipe parabola silinder, suhu tertinggi, daya masak, efisiensi

Abstract

Cylindrical parabolic solar cooker has a half-tube shaped with a diameter of $43 \mathrm{~cm} \times 63 \mathrm{~cm}$, has a variety of absorber materials, that is aluminum, copper and brass with a diameter of $41 \mathrm{~cm} \times 61 \mathrm{~cm}$ and a thickness of $0.02 \mathrm{~mm}$. The choice of material used for the conductivity value of the material. Performance tests are carried out for 6 days starting at 10:00 - 14:00 or for 240 minutes, including measurements of solar radiation, water temperature, absorber temperature and ambient temperature. The test was conducted at the Engineering Building in Politeknik Negeri Jember. Measurement data is used to calculate cooking power, standard cooking power and solar cooker efficiency. The highest temperature of cooking water is on the brass stove with absorber brass material at the fifth test of $80.25{ }^{\circ} \mathrm{C}$ at $12: 20$, the highest cooking power on the 4th day of the aluminum solar cooker absorber material that is equal to $18.46 \mathrm{~W}$, the highest cooker efficiency found on the aluminum material cooker in the first test of $25.57 \%$ at $13: 10$ WIB. The resulting efficiency is influenced by solar radiation, the difference between the initial and final temperatures and the length of time in the cooking process.

Keywords: Cylindrical parabolic solar cooker, higest temperature, cooking power, efficiency

\section{Pendahuluan}

Energi matahari merupakan sumber utama yang memancarkan radiasi ke bumi sehingga mampu menjaga kestabilan kehidupan. Energi matahari juga merupakan sumber energi baru terbarukan yang menawarkan energi alternatif berupa irradiasi.

Indonesia terletak di garis katulistiwa, sehingga Indonesia mempunyai sumber energi surya yang berlimpah dengan intensitas radiasi matahari rata-rata sekitar $4,8 \mathrm{kWh} / \mathrm{m}^{2}$ per hari di seluruh wilayah. Menurut Kementrian Energi dan Sumber Daya Mineral dalam Anhar dkk (2017), Indonesia mempunyai cuaca kondisi cerah pertahun (sunshine hours annually) adalah sekitar 2.975 jam atau 124 hari sedangkan rata-rata lamanya penyinaran sekitar 8,2 jam per hari .

Penelitian terdahulu menunjukkan temperature tertinggi kompor sebesar $74^{\circ} \mathrm{C}$ dengan efisiensi yang dihasilkan $41,48 \%$ dengan kompor surya tipe parabola silinder menggunakan penyimpan panas dengan system kompor terbuka (Yanuartanto, 2009).

Penelitian ini menggunakan kompor surya tipe parabola silinder dengan variasi bahan absorber alumunium, tembaga dan kuningan karena absorber menangkap atau penyerap panas dari radiasi matahari sehingga diharapkan memberikan pengaruh yang sangat signifikan dalam proses pemasakan. Penggunaan logam sebagai media penyimpan panas berfungsi untuk menjaga temperatur pada ruang pemasakan agar tetap stabil. Luasan yang digunakan kompor yaitu setengah tabung menyesuaikan dengan kerangka kompor, dan terdapat reflektor cermin sebagai pemusatan panas dari radiasi matahari ke titik api kompor dengan ditunjang adanya kaca transparan yang akan mengisolasi panas sehingga tidak terbuang ke lingkungan dan mempengaruhi kinerja kompor dalam proses pemasakan.

Tujuan penelitian ini adalah untuk mengetahui suhu tertinggi dan efisiensi tertinggi yang bias dihasilkan oleh kompor surya tipe parabola silinder dengan variasi bahan absorber.

\section{Metode Penelitian}

\subsection{Perancanaan Teknik Kompor Surya Tipe Parabola} Silinder

Dalam proses pembuatan desain kompor surya terdapat sisi luar kompor yang terbuat dari kayu sebagai casing kompor. Desain kompor surya tipe parabola silinder dapat dilihat pada Gambar 1. 


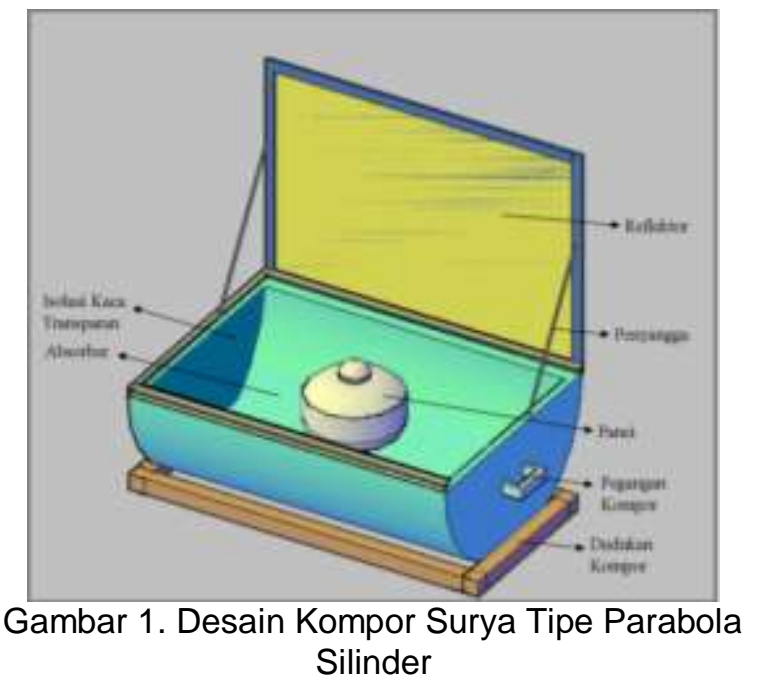

Ruang masak yang digunakan pada kompor surya menggunakan sudut setengah melingkar. Pada ruang masak kompor terdapat Styrofoam yang berguna sebagai isolasi yang diatasnya terdapat bahan absorber seperti aluminium, tembaga dan kuningan, dengan dimensi pada Tabel 1.

Tabel 1. Dimensi Ruang Masak

\begin{tabular}{cccccc}
\hline Parameter & Bahan & $\begin{array}{c}\text { Diameter } \\
(\mathbf{c m})\end{array}$ & $\begin{array}{c}\text { Panjang } \\
(\mathbf{c m})\end{array}$ & $\begin{array}{c}\text { Tinggi } \\
(\mathbf{c m})\end{array}$ & $\begin{array}{c}\text { Tebal } \\
(\mathbf{m m})\end{array}$ \\
\hline $\begin{array}{c}\text { Selubung } \\
\text { kompor }\end{array}$ & $\begin{array}{c}\text { Kertas } \\
\text { metalik }\end{array}$ & 41 & 61 & 20,5 & 0,7 \\
Knsulation & Kayu & 45 & 65 & 22,5 & 10 \\
Ruang & Alumufoam & 43 & 63 & 21,5 & 10 \\
Masak & Tembaga & 41 & 61 & 20,5 & 0,2 \\
& Kuningan & 41 & 61 & 20,5 & 0,2 \\
& 41 & 61 & 20,5 & 0,2 \\
\hline
\end{tabular}

Panci yang digunakan memiliki ukuran diameter $16,5 \mathrm{~cm}$ dan tinggi $10 \mathrm{~cm}$ dengan volume yang ditampung panci sebesar $0,002127 \mathrm{~m}^{3}$ sehingga mempu menampung air 1-2 Liter. Penyangga reflektor menggunakan pengait jendela dengan ukuran $25 \mathrm{~cm}$ sebanyak dua buah pada sisi kanan dan kiri kompor.

\subsection{Uji Performa Kompor Surya Tipe Parabola Silinder \\ Metode pengujian kompor surya menggunakan} Metode Water Boiling Test (WBT) Pengujian kompor surya dilakukan pada pukul 10:00 sampai 14:00 dengan interval waktu pengujian adalah 10 menit. Uji performa menggunakan air sebanyak $1 \mathrm{~L}$. Uji kompor surya memiliki standart sesuai dengan ASAE 2003 dengan mengukur suhu air $\left({ }^{\circ} \mathrm{C}\right)$, radiasi matahari $\left(\mathrm{W} / \mathrm{m}^{2}\right)$, suhu absorber $\left({ }^{\circ} \mathrm{C}\right)$, dan suhu lingkungan $\left({ }^{\circ} \mathrm{C}\right)$.

a. Menghitung Daya Masak

Daya masak adalah perubahan suhu air dikalikan dengan massa air dan panas jenis air yang hasilkan dibagi selang waktu pengukuran. Rumus daya masak adalah:

$\mathrm{P}_{\mathrm{i}}=\frac{\left(T_{22}-T 1\right) \mathrm{m} \cdot \mathrm{C}}{\mathrm{t}}$

Dimana :

$\mathrm{P}_{\mathrm{i}}=$ Daya Masak $(\mathrm{W})$;

$\mathrm{T}_{2}=$ Temperatur Air Akhir $\left({ }^{\circ} \mathrm{C}\right)$;
$\mathrm{T}_{1}=$ Temperatur Air Awal $\left({ }^{\circ} \mathrm{C}\right)$;

$\mathrm{m}=$ Massa Air $(\mathrm{Kg})$;

$\mathrm{C}=$ Panas Jenis air $\left(4186 \mathrm{~J} / \mathrm{Kg}^{\circ} \mathrm{C}\right)$;

$\mathrm{T}=$ Interval waktu (s).

b. Standarisasi Daya Masak

Standarisasi masak merupakan daya masak yang dikali dengan dengan radiasi rata-rata. Rumus standarisasi daya masak adalah:

$\mathrm{P}_{\mathrm{s}}=\mathrm{P}_{\mathrm{i}}\left(700 / \mathrm{l}_{\mathrm{i}}\right)$

Dimana:

$\mathrm{P}_{\mathrm{s}}=$ Standarisasi Daya Masak (W);

$\mathrm{P}_{\mathrm{i}}=$ Interval Daya Masak (W);

$\mathrm{I}_{\mathrm{i}}=$ Interval Rata-Rata Solar Insolation $\left(\mathrm{W} / \mathrm{m}^{2}\right)$.

c. Perhitungan Efisiensi Termal Kompor Surya

Efisiensi kompor menunjukkan ukuran performa kompor yang dihasilkan dalam proses pengujian, rumus efisiensi adalah:

(n) $=\frac{Q_{\text {out }}}{Q_{\text {in }}} \times 100 \%$

Dimana:

$\mathrm{Q}_{\text {in }}=$ Daya yang diterima kompor $(\mathrm{W})$;

$\mathrm{Q}_{\text {out }}=$ Energi yang diterima air (J).

Sedangkan energi yang diterima kompor merupakan hubungan antara luas permukaan kompor dengan radiasi matahari yang didapatkan rumus (Muin dkk, 2017):

$\mathrm{Q}_{\text {in }}=\mathrm{A}_{\mathrm{c}} \cdot$ Total Ir $(4)$

Dimana:

$\mathrm{Q}_{\mathrm{in}}=$ Daya yang diterima kompor (W);

$A_{c}=$ Luas permukaan kompor $\left(m^{2}\right)$;

$\mathrm{I}_{\mathrm{r}} \quad=$ Intensitas radiasi matahari $\left(\mathrm{W} / \mathrm{m}^{2}\right)$.

$Q_{\text {out }}$ merupakan energi yang diterima oleh air sehingga energi tersebut digunakan acuan untuk memperoleh hasil efisiensi kompor, $Q_{\text {out }}$ dapat diperoleh menggunakan rumus sebagai berikut:

$\mathrm{Q}_{\text {out }}=\mathrm{m} \cdot \mathrm{C}\left(\mathrm{T}_{2}-\mathrm{T}_{1}\right)$

Dimana:

$\mathrm{Q}_{\text {out }}=$ Energi yang diterima air $(\mathrm{J})$;

$\mathrm{M} \quad=$ Masa air $(\mathrm{Kg})$;

$\mathrm{Cp}=$ Panas Jenis air $\left(4186 \mathrm{~J} / \mathrm{kg}{ }^{\circ} \mathrm{C}\right) ;$

$\mathrm{T}_{2}=$ Temperatur akhir air $\left({ }^{\circ} \mathrm{C}\right)$;

$\mathrm{T}_{1}=$ Temperatur awal air $\left({ }^{\circ} \mathrm{C}\right)$.

\section{Hasil dan Pembahasan}

3.1. Rancang Bangun Kompor Surya Tipe Parabola Silinder

Desain kompor ini merupakan kompor surya tipe parabola silinder yang bidangnya membentuk setengah tabung, hal tersebut difungsikan untuk mendapatkan titik api kompor pada bidang bawah yang mengerucut. Variasi kompor surya tipe parabola silinder menggunakan absorber plat alumunium, tembaga dan kuningan dengan ukuran diameter $41 \mathrm{~cm}$ x $61 \mathrm{~cm}$ dengan ketebalan $0,02 \mathrm{~mm}$, sehingga menghasilkan ketinggian kompor $20,5 \mathrm{~cm}$. Secara teori semakin besar luas bidang pemasakan maka semakin besar pula intensitas radiasi yang masuk ke dalam kompor. Kompor surya ini dilengkapi dengan reflektor cermin berfungsi untuk memantulkan radiasi matahari sehingga dapat meningkatkan irradiasi yang masuk dalam kompor. Hasil rancang bangun kompor surya tipe parabola silinder disajikan dalam Gambar 2. 


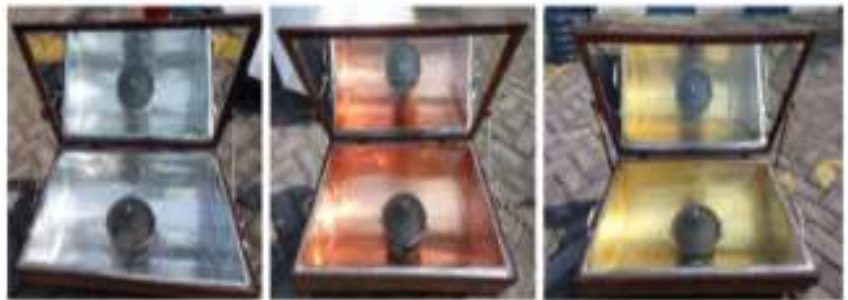

Gambar 2. Kompor Surya Tipe Parabola Silinder

\subsection{Temperature Tertinggi Kompor Surya Tipe \\ Parabola Silinder}

Hasil pengujian didapatkan suhu tertinggi air pemasakan pada setiap variasi absorber pada pengujian ke-5, mendapatkan hasil gambar grafik sebagai parameter uji performa kompor surya seperti Gambar 3 dan Gambar 4, menunjukkan kondisi irradiasi dan kecepatan angin pada hari tersebut.

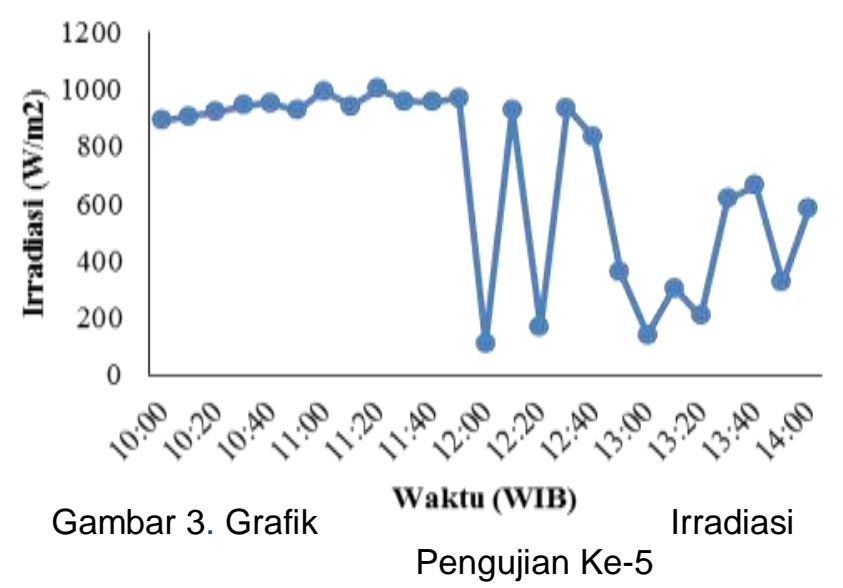

Irradiasi tertinggi terdapat pada pukul 11:20 sebesar $1001 \mathrm{~W} / \mathrm{m}^{2}$, sedangkan awal pengujian menghasilkan $890 \mathrm{~W} / \mathrm{m}^{2}$ dan akhir pengujian sebesar $582 \mathrm{~W} / \mathrm{m}^{2}$. Kondisi stabil irradiasi bertahan sampai pukul 11:50. irradiasi yang dihasilkan maka berpengaruh dengan naiknya suhu air sebagai media pemasakannya.

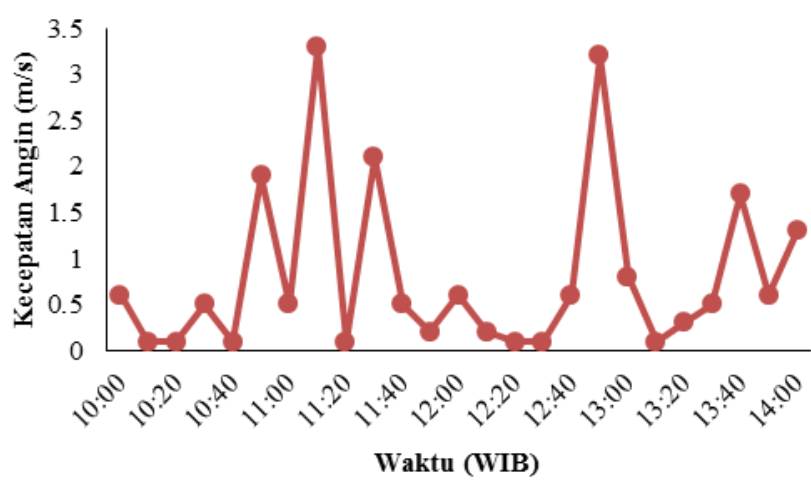

Gambar 4. Grafik Kecepatan Angin Pengujian Ke-5

Kecepatan angin tertinggi pada pengujian ke-5 terdapat pada pukul 11:10 sebesar $3,3 \mathrm{~m} / \mathrm{s}$. Awal pengujian menghasilkan $0,6 \mathrm{~m} / \mathrm{s}$ dan akhir pengujian menghasilkan $1,3 \mathrm{~m} / \mathrm{s}$. Sedangkan hasil pengujian kompor dihasilkan Gambar 5, Gambar 6 dan Gambar 7.

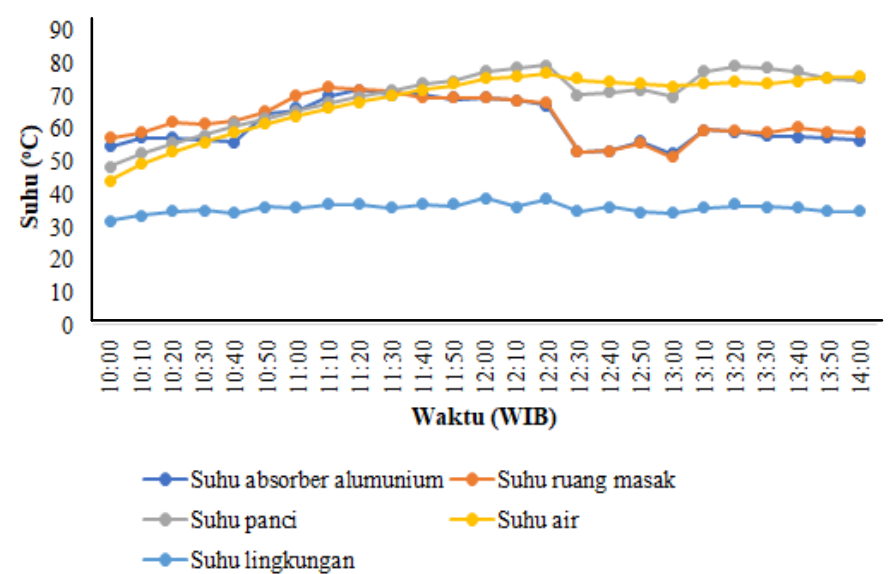

Gambar 5. Grafik Pengamatan Kompor Surya Absorber Alumunium Pengujian Ke-5

Kompor Surya absorber alumunium pengujian Ke-5 menunjukkan hasil suhu air tertinggi pengujian sebesar $76,8^{\circ} \mathrm{C}$ pada pukul $12: 20$, suhu absorber yang didapat sebesar $67,2^{\circ} \mathrm{C}$, suhu ruang masak $67,5^{\circ} \mathrm{C}$, suhu panci $79,4^{\circ} \mathrm{C}$, suhu lingkungan $38,5^{\circ} \mathrm{C}$, irradiasi $167 \mathrm{~W} / \mathrm{m}^{2}$, dan kecepatan angin sebesar $0,1 \mathrm{~m} / \mathrm{s}$, sehingga menghasilkan daya pemasakan $16,31 \mathrm{~W}$ dan efisiensi $18,60 \%$.

Performa kompor dipengaruhi irradiasi dan kecepatan angin yang dihasilkan. Semakin tinggi irradiasi yang dihasilkan berbanding lurus dengan suhu yang dihasilkan. Alumunium memiliki nilai suhu terendah namun memiiki sifat refleksivitas tertinggi diantara bahan lain, sehingga alumununium memiliki kondisi lebih stabil diantara bahan lain.

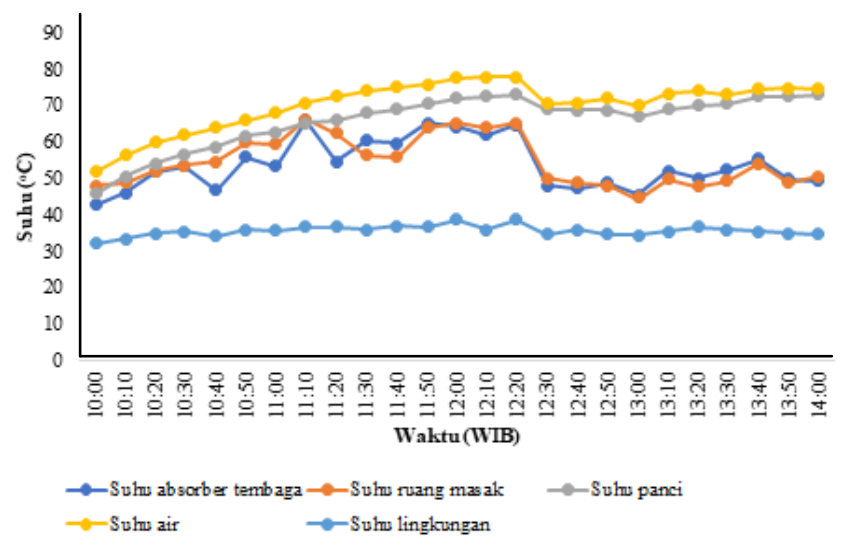

Gambar 6. Grafik Pengamatan Kompor Surya Absorber Tembaga Pengujian Ke-5

Pengujian ke-5 kompor surya absorber tembaga menghasilkan suhu air tertinggi pengujian pada pukul $12: 10$ sebesar $77,8^{\circ} \mathrm{C}$ dengan suhu absorber $61,7^{\circ} \mathrm{C}$, suhu ruang masak $63,65{ }^{\circ} \mathrm{C}$, suhu panci $72,2{ }^{\circ} \mathrm{C}$, suhu lingkungan $36,2{ }^{\circ} \mathrm{C}$, irradiasi $925 \mathrm{~W} / \mathrm{m}^{2}$ dan kecepatan angin sebesar $0,2 \mathrm{~m} / \mathrm{s}$, sehingga mendapatkan daya pemasakan 13,62 $\mathrm{W}$ dan efisiensi $2,80 \%$.

Absorber tembaga memiliki sifat mudah menyerap serta melepas panas, dan mudah dipengaruhi suhu lingkungan. Sehingga semakin rendah kondisi baik dari irradiasi dan kecepatan angin sangat mempengaruhi performa pemasakan kompor absorber tembaga. Absorber tembaga cepat untuk menyerap dan menghantarkan panasnya, terlihat suhu 
yang dihasilkan tembaga lebih tinggi dibandingkan suhu air absorber alumununiun namun untuk mempertahakan suhu pemasakan tembaga memiliki nilai terendah.

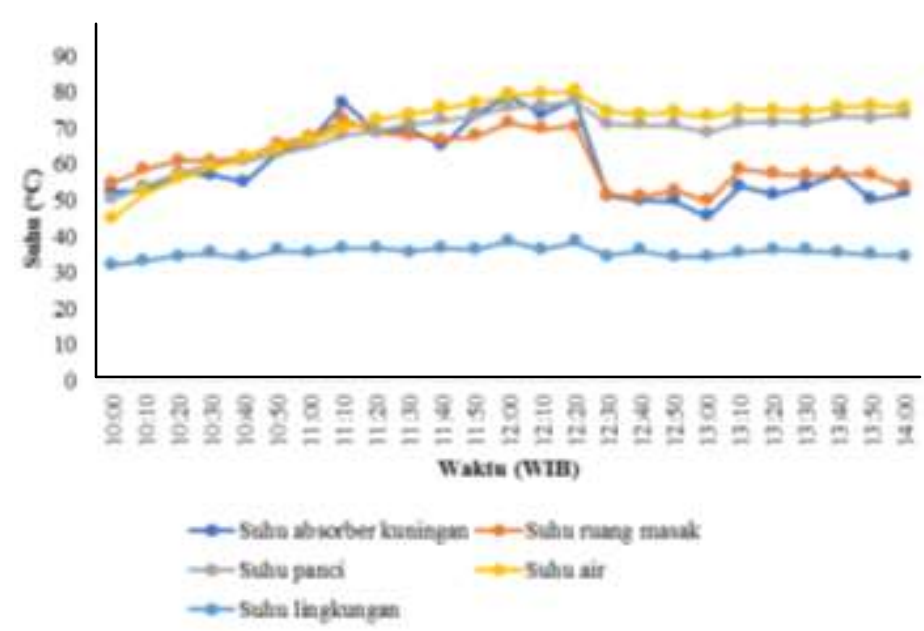

Gambar 7. Grafik Pengamatan Kompor Surya Absorber Kuningan Pengujian Ke-5

Kuningan mendapatkan suhu tertinggi air pada pukul 12:20 sebesar $80,25{ }^{\circ} \mathrm{C}$, suhu absorber 77,95 ${ }^{\circ} \mathrm{C}$, suhu ruang masak $70,55{ }^{\circ} \mathrm{C}$, suhu panci $77,2{ }^{\circ} \mathrm{C}$, suhu lingkungan $38,5{ }^{\circ} \mathrm{C}$, irradiasi $167 \mathrm{~W} / \mathrm{m}^{2}$ dan kecepatan angin $0,1 \mathrm{~m} / \mathrm{s}$, sehingga menghasilkan daya pemasakan $16,78 \mathrm{~W}$ dan efisiensi $19,14 \%$.

Pengujian awal mendapatkan suhu air sebesar $44,8{ }^{\circ} \mathrm{C}$, suhu absorber $52,35{ }^{\circ} \mathrm{C}$, suhu ruang masak $54,6{ }^{\circ} \mathrm{C}$, suhu panci $50,25^{\circ} \mathrm{C}$, suhu lingkungan 32,05 ${ }^{\circ} \mathrm{C}$, irradiasi $890 \mathrm{~W} / \mathrm{m}^{2}$ dan kecepatan angin $0,6 \mathrm{~m} / \mathrm{s}$. Suhu tertinggi yang dihasilkan absorber $78,9^{\circ} \mathrm{C}$ pukul $12: 00$, suhu ruang masak $72,45^{\circ} \mathrm{C}$ pukul $11: 10$, suhu panci $77,2{ }^{\circ} \mathrm{C}$ pukul 12:20. Penurunan suhu air yang dihasilkan kuningan tidak menunjukkan signifikan, berbeda dengan bahan tembaga karena tingkat stabil absorber kuningan leih tinggi dibandingkan tembaga. Suhu air yang dihasilkan kuningan memiliki nilai tertinggi diantara bahan lain dikarenakan kuningan sangat mudah menyerap panas pada proses pemasakan dan suhu pada absorber dan ruang pemasakan yang dihasilkan memiliki nilai tertinggi sehingga berbanding lurus dengan air pemasakan yang dihasilkan.

3.3 Perbandingan Uji kinerja Kompor Surya Tipe Parabola Silinder dengan Variasi Bahan Absorber

Perbandingan hasil pengujian yang telah dilakukan menunjukkan bahwa perubahan suhu air dipengaruhi oleh besarnya radiasi matahari. Banyaknya pengulangan pengujian diharapkan mempu memberikan variasi data sehingga dapat membandingkan efisiensi masing-masing kompor surya tipe parabola silinder. Hasil Efisensi yang dihasilkan kompor dapat dilihat pada Tabel 2, Tabel 3 dan Tabel 4.
Tabel 2. Data Studi Kompor Surya Tipe Parabola

Silinder dengan Variasi Absorber Alumunium

\begin{tabular}{|c|c|c|c|c|c|c|c|}
\hline \multirow{2}{*}{ No } & \multirow{2}{*}{ Parameter } & \multicolumn{6}{|c|}{ Hari Ke- } \\
\hline & & 1 & 2 & 3 & 4 & 5 & 6 \\
\hline \multirow{3}{*}{1} & T air & & & & & & \\
\hline & Maksimal & & & & & & 7505 \\
\hline & Waktu & /2,55 & 64,60 & 64,85 & 70,10 & $/ 6,8$ & $/ 5,95$ \\
\hline \multirow[t]{3}{*}{2} & T.Max & & & & & & \\
\hline & (WIB) & $13: 10$ & $14: 00$ & $12: 40$ & $12: 10$ & $12: 20$ & $14: 00$ \\
\hline & Durasi & & & & & & \\
\hline \multirow[t]{2}{*}{3} & Waktu & & & & & & \\
\hline & $\begin{array}{l}\text { Tmax } \\
\text { (Menit) }\end{array}$ & 190 & 240 & 160 & 130 & 140 & 240 \\
\hline \multirow{2}{*}{4} & Daya & & & & & & \\
\hline & Masak (W) & 15,98 & 8,04 & 10,23 & 18,46 & 16,31 & 9.03 \\
\hline 5 & $\begin{array}{l}\text { Efisiensi } \\
(\%)\end{array}$ & 25,57 & 2,75 & 8,63 & 20,33 & 18,60 & 10,17 \\
\hline
\end{tabular}

Efisiensi tertinggi yang dihasilkan absorber pada hari pertama yaitu $25,57 \%$, terdapat pada pukul 13:10 dengan suhu air maksimal $72,55{ }^{\circ} \mathrm{C}$ dan daya pemasakan 15,98 W. Absorber bahan alumunium memiliki nilai efisiensi tertinggi diantara bahan yang lain dikarenakan alumunium memiliki daya serap serta dapat memantulkan radiasi matahari sehingga dapat meningkatkan suhu dalam proses pemasakan. Semakin tinggi tempat pengujian maka semakin tinggi pula kecepatan angin yang dihasilkan.

Tabel 3. Data Studi Kompor Surya Tipe Parabola Silinder dengan Variasi Absorber Tembaga

\begin{tabular}{|c|c|c|c|c|c|c|c|}
\hline \multirow{2}{*}{ No } & \multirow{2}{*}{ Parameter } & \multicolumn{6}{|c|}{ Hari Ke- } \\
\hline & & 1 & 2 & 3 & 4 & 5 & 6 \\
\hline & Tair & & & & & & \\
\hline & Maksimal & 72,2 & & 64,0 & 75,3 & 77,8 & 72,5 \\
\hline \multirow[t]{3}{*}{1} & $\left({ }^{\circ} \mathrm{C}\right)$ & 5 & 61,25 & 0 & 5 & 0 & 0 \\
\hline & Waktu & & & & & & \\
\hline & T.Max & $13: 0$ & & $12: 4$ & $12: 0$ & $12: 1$ & $13: 5$ \\
\hline \multirow[t]{4}{*}{2} & (WIB) & 0 & $13: 50$ & 0 & 0 & 0 & 0 \\
\hline & Durasi & & & & & & \\
\hline & Waktu & & & & & & \\
\hline & Tmax & & & & & & \\
\hline \multirow[t]{2}{*}{3} & (Menit) & 180 & 230 & 160 & 120 & 130 & 230 \\
\hline & Daya & 15,3 & & & 18,3 & 13,6 & \\
\hline \multirow[t]{2}{*}{4} & Masak (W) & 1 & 7,01 & 9,90 & 3 & 2 & 8,33 \\
\hline & Efisiensi & & & & & & \\
\hline 5 & $(\%)$ & 3,34 & 2,30 & 8,34 & 3,02 & 2,80 & 3,74 \\
\hline
\end{tabular}

Efisiensi bahan tembaga tertinggi terdapat pada pengujian ke-6 sebesar 8,35 \%, pada pukul 12:40 dengan daya pemasakan 9,90 W. Sedangkan efisiensi terendah yaitu pada pengujian ke-5 sebesar 2,30\% pada pukul $13: 50$, suhu air $61,25{ }^{\circ} \mathrm{C}$, dan daya pemaskan 7,01 W. Tembaga memiliki nilai efisiensi terendah diantara 2 variasi lainnya, hal tersebut dikarenakan sifat tembaga mudah menyerap dan melepas kalor sehingga mengakibatkan suhu absorber dan panci mudah berpengaruh. Kecepatan angin sangat mempengaruhi suhu yang dihasilkan pada kompor bahan absorber tembaga karena semakin tinggi kecepatan angin maka semakin banyak suhu yang akan hilang melalui celah kecil antara isolator kaca dan bidang kompor. 
Tabel 4. Data Studi Kompor Surya Tipe Parabola Silinder dengan Variasi Absorber Kuningan

\begin{tabular}{|c|c|c|c|c|c|c|c|}
\hline \multirow{2}{*}{ No } & \multirow{2}{*}{$\begin{array}{c}\text { Paramete } \\
\mathbf{r}\end{array}$} & \multicolumn{6}{|c|}{ Hari Ke- } \\
\hline & & 1 & 2 & 3 & 4 & 5 & 6 \\
\hline & $\mathrm{T}$ air & & & & & & \\
\hline & Maksimal & & 63,1 & 66,1 & & & 75,7 \\
\hline 1 & $\begin{array}{l}\left({ }^{\circ} \mathrm{C}\right) \\
\text { Waktu }\end{array}$ & 72,20 & 5 & 0 & 75,20 & 80,25 & 0 \\
\hline & T.Max & & $13: 5$ & $12: 4$ & $14: 0$ & & \\
\hline 2 & (WIB) & $13: 10$ & 0 & 0 & 0 & $12: 20$ & 13:50 \\
\hline & Waktu & & & & & & \\
\hline 3 & $\begin{array}{l}\text { Tmax } \\
\text { (Menit) } \\
\text { Daya }\end{array}$ & 190 & 230 & 160 & 240 & 140 & 230 \\
\hline 4 & Masak & 1521 & 728 & 865 & $\begin{array}{c}10,8 \\
4\end{array}$ & 16.78 & 742 \\
\hline & Efisiensi & & & & & & \\
\hline 5 & $(\%)$ & 24,34 & 3,35 & 7,29 & 10,2 & 19,14 & 3,33 \\
\hline
\end{tabular}

Efisiensi tertinggi yang dihasilkan yaitu 24,34\% pada pengujian pertama pukul 13:10, suhu air 72,20 ${ }^{\circ} \mathrm{C}$ dan daya pemasakan $15,21 \mathrm{~W}$, sedangkan efisiensi terendah terdapat pada pengujian ke-6 pukul 13:50 sebesar $3,33 \%$ dengan suhu air $75,70{ }^{\circ} \mathrm{C}$ dan daya pemasakan 7,42 W. Efisiensi yang dihasilkan dipengaruhi irradiasi, beda suhu serta waktu pemasakan. Semakin tinggi beda suhu dengan irradiasi rendah serta waktu pemasakan cepat maka efisiensi yang dihasilkan semakin besar. Berbeda jika beda suhu rendah dengan irradiasi yang dihasilkan tinggi serta waktu pemasakan lama maka efisiensi yang dihasilkan kecil.

Gambar 8 dan Gambar 9 menunjukkan grafik perbedaan secara sigifikan performansi kompor surya baik pada daya pemasakan kompor dan efisiensi yang dihasilkan:

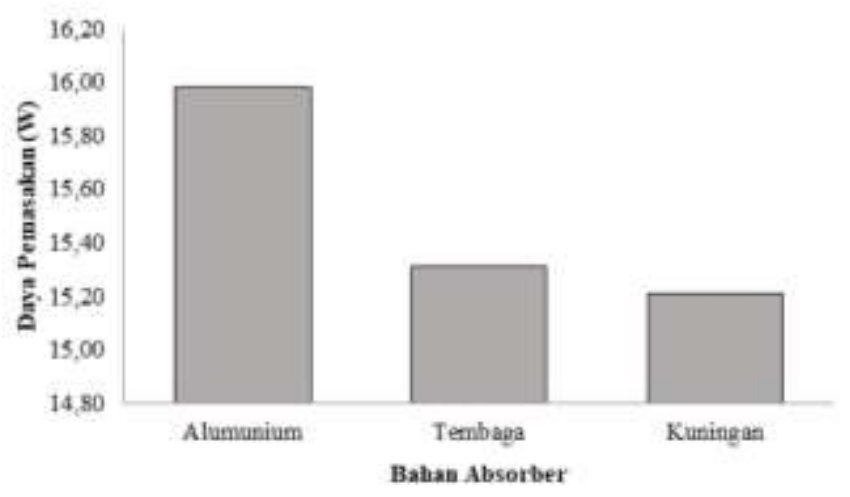

Gambar 8. Grafik Daya Pemasakan Kompor Surya Pengujian Pertama

Alumunium memiliki daya pemasakan tertinggi diantara bahan lain yaitu 15,98 $\mathrm{W}$ dengan beda suhu $43,95{ }^{\circ} \mathrm{C}$ pada suhu tertinggi air yang dihasilkan pukul 13:10. Sedangkan kuningan memilki daya pemasakan terendah yaitu 15,21 dengan beda suhu $42,70{ }^{\circ} \mathrm{C}$ pukul 13:10. Suhu tertinggi yang dihasilkan alumunium dan kuningan pada waktu yang sama, sedangkan tembaga memiliki capaian suhu tertinggi lebih cepat yaitu pukul 13:00 dengan beda suhu $39,50{ }^{\circ} \mathrm{C}$ sehingga mendapatkan daya pemasakan $15,31 \mathrm{~W}$. Lama waktu pemasakan untuk mencapai suhu tertinggi mempengaruhi daya pemasakan yang dihasilkan, semakin cepat waktu pemasakan maka semakin besar pula daya pemasakan yang dihasilkan. Beda suhu yang dihasilkan dari awal pemasakan hingga mencapai suhu tertinggi juga mempengaruhi daya masak yang dihasilkan, semakin besar beda suhu yang dihasilkan maka semakin berbanding lurus dengan daya pemasakan yang dihasilkan.

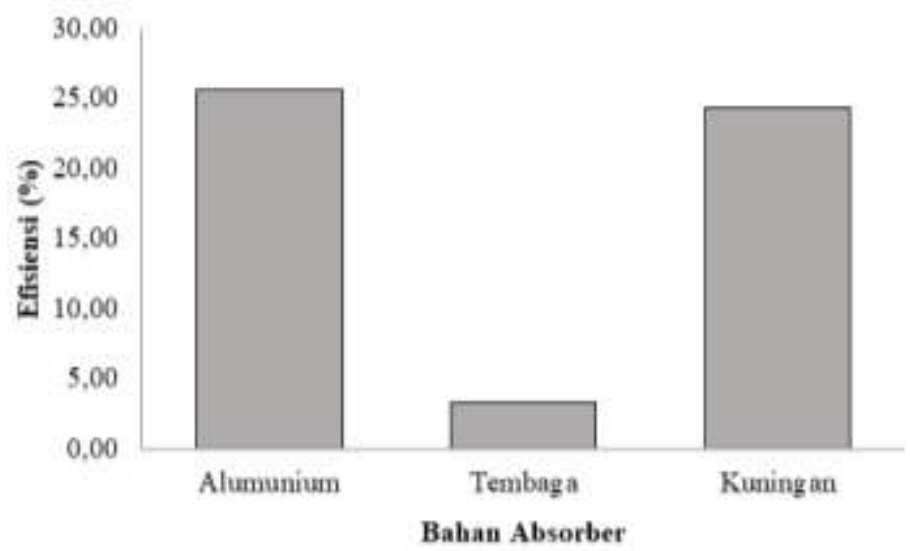

Gambar 9. Grafik Efisiensi Kompor Surya Pengujian Pertama

Efisiensi alumunium memiliki nilai tertinggi diantara bahan lain yaitu 25,57 \% dengan Qin 40,35 W dan Qout 15, 98 W pukul 13:10, sedangkan tembaga memiliki efisiensi terendah diantara bahan lain yaitu 3,34 \% dengan Qin 457,80 W dan Qout 15,31 W pukul 13:00. Perbedaan waktu pengukuran menghasilkan irradiasi yang berbeda pula, semakin besar irradiasi maka semakin besar pula Qin yang dihasilkan. Nilai Qin lebih tinggi dibandingkan Qout maka efisiensi yang dihasilkan semakin kecil karena antara kalor masuk dan kalor yang digunakan tidak seimbang dan banyak yang terbuang sehingga menyebabkan efisiensi yang dihasilkan rendah.

\section{Simpulan}

Penelitian kompor surya tipe parabola silinder berbentuk setengah tabung dengan ukuran diameter $43 \mathrm{~cm} \times 63 \mathrm{~cm}$, memiliki variasi bahan absorber yaitu alumunium, tembaga dan kuningan dengan ukuran diameter $41 \mathrm{~cm} \times 61 \mathrm{~cm}$ dan ketebalan 0,02 mm. Pemilihan bahan yang digunakan terdapat pada nilai konduktivitas bahan. Uji performa dilakukan selama 6 hari mulai pukul 10:00- 14:00 atau selama 240 menit, meliputi pengukuran radiasi matahari, suhu air, suhu absorber dan suhu lingkungan. Kesimpulan yang didapatkan dari penelitian ini adalah:

1. Rancang bangun kompor surya ini menggunakan kerangka kayu mahoni dengan ukuran diameter 45 $\mathrm{cm} \times 65 \mathrm{~cm}$ dengan ketebalan $1 \mathrm{~cm}$, kemudian diberi sterofoam dengan ukuran yang sama yaitu $43 \mathrm{~cm} \times 63 \mathrm{~cm}$ dengan ketebalan $1 \mathrm{~cm}$. Setelah sterofoam diberi kertas metalik dan absorber yang dengan variasi aluminum, tembaga dan kuningan dengan ukuran diameter $41 \mathrm{~cm} \times 61 \mathrm{~cm}$;

2. Pengujian kompor menghasilkan data suhu air tertinggi kompor bahan kuningan pada pukul 12:20 pengujian ke- 5 sebesar $80,25^{\circ} \mathrm{C}$;

3. Efisiensi tertinggi yang dihasilkan kompor surya bahan absorber alumunium pengujian pertama 
sebesar $25,57 \%$, terdapat pada pukul 13:10 dengan suhu air maksimal $72,55{ }^{\circ} \mathrm{C}$ dan daya pemasakan $15,98 \mathrm{~W}$.

\section{Ucapan Terima Kasih}

Terimakasih kepada Prodi Teknik Energi Terbarukan Jurusan Teknik Politeknik Negeri Jember yang sudah memfasilitasi Laboratorium Teknik Energi Terbarukan dalam penyelesaian penelitian ini.

\section{Daftar Pustaka}

[1] Anhar, A.S., Sara,D.S., dan Siregar, H.D. 2017. Desain Prototipe Sel Surya Terkonsentrasi Menggunakan Lensa Fresnel. Jurnal Online Teknik Elektro Vol.2 No.3. Universitas Syiah Kuala. Banda Aceh.

[2] American Society of Agricultural Engineers. 2003. Testing and Reporting Solar Coker Performance. Ed ASSAE Press.

[3] Ashari, Yunus. 2009. Perpindahan Panas Dan Massa. Diktat Kuliah Universitas Persada. Jakata.

[4] Bailis, R, D. Ogle, N. MacCarty dan D. still. 2007. The Water Boiling Test (WBT). Shell Foundation.

[5] Buchori, Luqman. 2004. Buku Ajar Perpindahan Panas Bagian 1. Universitas Diponegoro. Semarang.

[6] Contaned Energy Indonesia. 2010. Buku Panduan Energi Yang Terbarukan. ISBN 1-8852013-29-2. Danida : Embassy of Denmark.

[7] Dwicaksono,M.B., Dan Rangguti,C. 2017. Perancangan, Pembuatan, Dan Pengujian Kompor Energi Matahari Portabel Tipe Parabola Kipas. Seminar Nasional Cendekiawan Ke 3. Universitas Trisakti. Jakarta.

[8] Entikaria Rachmanita, R., Suweni Muntini, M., Thawankaew, S., Chao-Moo, W., Vora-Ud, A., Seetawan, T., 2018. Fabrication and characterization of interdigital capacitors thin film by DC magnetron sputtering for measuring the permittivity of crude oil. Mater. Today Proc., The 3rd International Conference on Applied Physics and Materials Applications (ICAPMA 2017), 31 May-2 June 2017 5, 15192-15197. https://doi.org/10.1016/j.matpr.2018.04.081

[9] Fariska, Dewi. 2018. Studi Variasi Sudut Ruang Masak Pada Kompor Surya Tipe Box Dengan Menggunakan Reflektor Cermin. Skripsi. Politeknik Negeri Jember.

[10] Firdaus, Junda. 2018. Uji Performansi Tungku Tanah Liat Dengan Penambahan Abu Ampas Tebu Dan Abu Sekam Padi. Skripsi. Politeknik Negeri Jember.
[11] Haryadi dan Mahmudi, Ali. 2012.Perpindahan Panas.Buhu Bahan Ajar. Politeknik Negeri Bandung.

[12] Hatuwe, A., Dan Patty, A.A.2010. Studi Eksperimen Kinerja Kompor Surya Tipe Kotakdengan Kombinasi Reflektor Datar Dan Parabola . Jurnal Teknologi, Volume 5 Nomor 2. Politeknik Negeri Ambon.

[13] Marwani. 2011. Potensi Penggunaan Kompor Energi Surya Untuk Kebutuhan Rumah Tangga. Prosiding Seminar Nasional Avoer Ke-3. Universitas Sriwijaya. Palembang.

[14] Monalisa, Pingki. 2018. Uji Performansi Kompor Surya Tipe Kombinasi Dengan Penambahan Reflektor Datar. Skripsi. Politeknik Negeri Jember.

[15] Muin,A., Veranika, R.M., Dan Badil,I. 2017.Perancangan Kompor Surya Serbaguna Dengan Susunan Absorber Yang Berfariasi.Jurnal Desiminasi Teknologi.Universitas Tridinanti.Palembang.

[16] Nugraha, Aditya. 2014. Analisis Pindah Panas Pada Sistem Pemanas Tambahan Alat Pengering Surya Hibrid-Tipe Rak Berputar Untuk Sawut Ubi Jalar. Skripsi. Insitut Pertanian Bogor.

[17] Riyadi, Irnanda. 2008. Rancang Bangun Kolektor Surya Menggunakan Absorber Kuningan Sebagai Teknologi Alternatif Sumberenergithermal. Prosiding Seminar Nasional Sains Dan Teknologili 2008. Universitas Lampung.

[18] Ramadhi, Afris. 2014. Pengaruh Luas Tangkap Reflektor Terhadap Kinerja Kompor Surya Tpe Parabolik. Skripsi. Universitas Lampung.

[19] Rachmanita, R.E., 2019. The High Capacitance for Electrode Structure of Interdigital Capacitor Thin Film Models. SNRU J. Sci. Technol. 11, 5563.

[20] Rachmanita, R.E., Ahmadi, H., 2019. Aplikasi Interdigital Capacitor Sensor (IDCS) dalam pengukuran permitivitas relatif Crude Oil. J. Pendidik. Fis. Dan Keilmuan JPFK 5. https://doi.org/10.25273/jpfk.v5i2.4011

[21] Rachmanita, R.E., Ahmadi, H., 2019. Perancangan Perancangan Sistem Pengukuran Kapasitansi Crude Oil Menggunakan Interdigital Capasitors (IDCs) Berbasis Arduino Uno. JIPFRI (Jurnal Inovasi Pendidikan Flsika dan Riset IImiah) 3(2), 54-61.

[22] Sitompul, Rislima. 2011. Teknologi Energi Terbarukan Yang Tepat Untuk Aplikasi Di Masyarakat Pedesaan. Pnpm Support Facility (Psf). Jakarta.Suarsana. 2017. Diktat IImu Material Teknik.Universitas Udayana.Denpasar. 
[23] Yanuartanto, T.Y. 2009. Kompor Surya Menggunakan Penyimpanan Panas Dengan Variasi Ketinggian Kompor. Skripsi.Universitas Sanata Dharma. Yogyakarta.

[24] Yuliarto,Brian. 2017. Memanen Energi Matahari.Penerbit Itb. Bandung.

[25] Yuliatmaja, M.R.2009. Ajian Lama Penyinaran Matahari Dan Intensitas Radiasi Matahari Terhadap Pergerakan Semu Matahari Saat Solstice Di Semarang (Studi Kasus Badan Meteorologi Dan Geofisika Stasiun Klimatologi Semarang Pada Bulan Juni Dan September Tahun 2005 Sampai Dengan 2007).Skripsi. Universitas Negeri Semarang. 